\title{
Root Growth and Soil Nitrogen Depletion by Onion, Lettuce, Early Cabbage and Carrot
}

\author{
K. Thorup-Kristensen \\ Danish Institute of Agricultural Scicences \\ Department of Horticulture \\ 5792 Aarslev \\ Denmark
}

Keywords: Green manure, soil nitrogen, rooting depth, root growth rate, vetch, rye, ryegrass

\begin{abstract}
Experiments examining root growth, the utilization of $N$ and the effect of green manures were carried out on four vegetable crops. Large differences were observed both in rooting depth penetration rates, and in final rooting depth and distribution. Onion had a very low depth penetration rate, carrot an intermediate rate, and lettuce and cabbage showed high rates. A combination of depth penetration rates and duration of growth determined rooting depth at harvest. Therefore, lettuce, which had a very short growing season, had a shallow root system at harvest, whereas carrot with a lower depth penetration rate but a long growing season had deep rooting at harvest. The final rooting depth of the vegetables varied from approximately $0.3 \mathrm{~m}$ for onion to more than $1.0 \mathrm{~m}$ for carrot and early cabbage. Carrot and cabbage were able to utilize $N$ from deeper soil layers, not available to onion and lettuce. The ability of green manure crops to concentrate available $\mathrm{N}$ in the upper soil layers was especially valuable when they were grown before the two shallow rooted crops.
\end{abstract}

\section{INTRODUCTION}

Very significant differences in root growth exist amongst vegetable crops, and effective rooting depths from $0.2 \mathrm{~m}$ to more than $1.0 \mathrm{~m}$ have been reported (Burns, 1980; Greenwood et al. 1982; Jackson, Stivers, 1993; Jackson, 1995; Kuhlmann, 1990; Schenk et al. 1991; Smit et al. 1996; Thorup-Kristensen, 1993; Thorup-Kristensen, 1998; ThorupKristensen, Sørensen, 1999; Thorup-Kristensen, Van den Boogaard, 1998 and 1999). Few, if any, attempts have been made to test whether some vegetable crops have rooting depths of more than $1.0 \mathrm{~m}$, though rooting depths of up to $2.0 \mathrm{~m}$ or more have been observed for close relatives, e.g. winter rape (Barraclough, 1989) and sugar beet (Peterson et al., 1979).

It is important to know the root growth of the vegetable crop species when trying to optimize the nitrogen use efficiency (NUE) in vegetable production, both at the crop level and at the crop rotation level. At the crop level, it is important to know the rooting depth when using various methods to estimate soil nitrogen supply to the crop. With the $\mathrm{N}_{\text {min }}$ method (Wehrmann et al., 1988) rooting depth must be known as it determines the relevant soil sampling depth for $\mathrm{N}_{\min }$ measurements. In simulation models (e.g. Greenwood et al. 1996), estimates of rooting depth development must be included as the rooting depth determines how much of the simulated soil inorganic $\mathrm{N}$ is actually available for the plants.

Information on root growth can also be used to design crop rotations with low $\mathrm{N}$ leaching losses and high overall NUE (Thorup-Kristensen and Grevsen, 1999). By placing deep-rooted crops or catch crops at points in the rotation where available $\mathrm{N}$ is present in deeper soil layers, total losses can be reduced significantly. By placing shallow rooted crops only where little $\mathrm{N}$ is available in deeper soil layers, nitrogen losses after these crops can be reduced. Growing catch crops can create a situation where most of the available $\mathrm{N}$ is present in upper soil layers with little in deeper soil layers (ThorupKristensen, Nielsen, 1998), and catch crops are thus of special value when grown before 
shallow rooted main crops.

In organic vegetable production, optimizing nitrogen use efficiency is especially important, both in order to protect the environment, and to secure the $\mathrm{N}$ supply for the crops. Catch crops and green manures can be used to reduce $\mathrm{N}$ losses and increase $\mathrm{N}$ supply for the crops, but they will affect the depth distribution of the available $\mathrm{N}$, as well as the total amount of available $\mathrm{N}$ in the soil (Thorup-Kristensen and Bertelsen, 1996).

The aim of the present work was to study the root growth of four vegetable crops, and their ability to utilize soil nitrogen from various depths in the soil. There was a further objective to study the ability of these crops to utilize nitrogen from green manures in organic rotations which had variable effects on depth distribution of available nitrogen.

\section{MATERIALS AND METHODS}

Green manure crops were established in early August, after harvest of a barley crop. The green manures were two winter hardy legumes (hairy vetch and crimson clover), two non-hardy legumes (common vetch and Egyptian clover) and two winter hardy non-legumes (winter rye and Italian ryegrass). The effect of the green manure crops was evaluated by comparison with plots with no green manure. The experiment was repeated twice, in 1996/97 and again in 1997/98, each time with three replicates.

The green manure crops were ploughed into the soil around $1^{\text {st }}$ April each year (Table 1) and no further fertilizer was added. The nitrogen content in the above ground plant parts (measured mid November) of the legume green manures was in the order of $100 \mathrm{~kg} \mathrm{~N} \mathrm{ha}^{-1}$, whereas rye and ryegrass contained between 20 and $40 \mathrm{~kg} \mathrm{~N} \mathrm{ha}^{-1}$. Onions were sown, and cabbage (with a short growing season) and lettuce were transplanted around the $1^{\text {st }}$ May. Carrots were sown in late May. In the second year the lettuce and cabbage crops were covered with fleece during the first weeks after planting, to prevent bird damage.

The soil was sampled for mineral $\mathrm{N}$ (one hour extraction in a $1 \mathrm{M} \mathrm{KCl}$ ) in November under the green manures and in May in all treatments; then again after the harvest of each vegetable crop, in the treatments with hairy vetch, common vetch and no green manure. At the November sampling, the soil was sampled to $1.0 \mathrm{~m}$ depth (four layers of $0.25 \mathrm{~m}$ each) but in May and at harvest it was sampled to $1.5 \mathrm{~m}$ depth (six layers of $0.25 \mathrm{~m}$ each). The green manures were sampled $\left(1.25 \mathrm{~m}^{2}\right)$ in November to determine biomass production and total $\mathrm{N}$ uptake, and the vegetable crops were sampled $\left(3 \mathrm{~m}^{2}\right)$ at harvest to determine yield, dry matter production and $\mathrm{N}$ uptake.

The root growth of the vegetable crops was determined by the minirhizotron method. The minirhizotrons were $70 \mathrm{~mm}$ in outer diameter, and had a total length of 1.5 $\mathrm{m}$ and were installed at $30^{\circ}$ from vertical. The observation depth was $1.0 \mathrm{~m}$ in the first year, but increased to $1.2 \mathrm{~m}$ in the second year. In 1997, minirhizotrons were installed in four randomly chosen plots for each of the vegetable species, in 1998 minirhizotrons were installed in the plots where hairy vetch or winter rye had been grown, i.e. six plots for each vegetable crop. In each of these plots, four minirhizotrons were installed, two minirhizotrons beneath the crop rows and two in the inter-row soil.

Root observations were made by lowering a mini-video camera into the minirhizotrons and recording the roots, which were visible on the minirhizotron surface. Two different measurements were made, Rooting depth was observed every second week during crop growth by observing the deepest single root on the upper left and upper right side of each minirhizotron. To determine root numbers, two vertical lines were painted along the minirhizotrons on the upper left and upper right side of the tubes respectively. At $40 \mathrm{~mm}$ intervals these lines were crossed by $40 \mathrm{~mm}$ long horizontal lines. Root intensity was recorded as the number of root intersections per metre line on the minirhizotrons.

\section{RESULTS AND DISCUSSION}

The root measurements confirmed that the four vegetables had very different root growth. At harvest, carrots and cabbages had deep and extensive root systems, whereas 
lettuce and onion had much shallower root systems (Figure 1). The differences in rooting depth at harvest were due to differences in rooting depth penetration rates as well as differences in the duration of the growing period. Lettuce and cabbage had high rooting depth penetration rates of approximately $1.2 \mathrm{~mm}$ day ${ }^{-1}{ }^{\circ} \mathrm{C}^{-1}$, slightly higher than the rate of $1.02 \mathrm{~mm}$ day ${ }^{-1}{ }^{\circ} \mathrm{C}^{-1}$ previously found for cauliflower (Thorup-Kristensen and Van den Boogaard, 1998). The difference in final rooting depth of these two crops was due to differences in the period they were allowed to grow, rather than to basic differences in the ability of the two species to develop their root systems.

The rate of rooting depth development was the same in both years, however, in 1998 the two transplanted crops were significantly faster to initiate root growth than in 1997, probably due to fleece covering during the first weeks after transplanting in 1998. Carrots had a rooting depth penetration rate of approx. $0.7 \mathrm{~mm}$ day ${ }^{-1}{ }^{\circ} \mathrm{C}^{-1}$, close to the rate of $0.76 \mathrm{~mm}$ day ${ }^{-1}{ }^{\circ} \mathrm{C}^{-1}$ previously estimated by Thorup-Kristensen and Van den Boogaard (1999). This rate was significantly lower than the rooting depth development rate of lettuce and cabbage, but because of the longer duration of the growing period, carrots were able to develop a root system, which was almost as deep as the root system of cabbage.

Onions had very slow rooting depth penetration, only about $0.2 \mathrm{~mm}$ day ${ }^{-1}{ }^{\circ} \mathrm{C}^{-1}$. Due to this low rate, the estimated rooting depth of onion at harvest was only 0.25 to 0.35 $\mathrm{m}$, even though onion had a longer growing season than cabbage.

The shallow rooted vegetables, onion and lettuce, left on average $70 \mathrm{~kg} \mathrm{~N} \mathrm{ha}^{-1}$ in the soil at harvest, whereas the deep rooted crops, carrot and cabbage, left only $31 \mathrm{~kg} \mathrm{~N}$ $\mathrm{ha}^{-1}$. The differences were especially pronounced in the $0.25 \mathrm{~m}$ to $1.0 \mathrm{~m}$ soil layers (Figure 2), exactly the soil layers where many roots were found under the deep rooted crops, but few or no roots under the shallow rooted crops. Carrot and cabbage have previously been found to be efficient in depleting the soil $\mathrm{N}$ reserves compared to the shallower rooted leek crop (Thorup-Kristensen and Sørensen, 1999).

The soil nitrogen depletion by carrot was close to the results of Thorup-Kristensen and Sørensen (1999) and Thorup-Kristensen and Van den Boogaard (1999). Cabbage was not as efficient as found by Thorup-Kristensen and Sørensen (1999), its soil depletion was more in line with the results obtained for various crucifer crops by (Rahn, 1992; Whitmore, 1996; Everaarts et al. 1996; Thorup-Kristensen and Van den Boogaard, 1998). This difference could be due to the long growing season of white cabbage in the experiment of Thorup-Kristensen and Sørensen (1999), which allowed the crop more time to develop a deep root system and, thus to deplete the soil more efficiently than brassica crops with a shorter growing period.

The green manures were found to have very different effects on $\mathrm{N}$ distribution in the soil profile in the spring $\mathrm{N}$ and on $\mathrm{N}$ supply for the vegetable crops. The two vetches increased the mineral $\mathrm{N}$ content in the soil by approximately $50 \mathrm{~kg} \mathrm{~N} \mathrm{ha}^{-1}$, whereas the rye and ryegrass had reduced he content by 25 and $55 \mathrm{~kg} \mathrm{~N}^{-1}$ respectively. After the grasses and hairy vetch, $85 \%$ and $72 \%$ of the mineral $\mathrm{N}$ was found in the top $0.5 \mathrm{~m}$ of the $1.5 \mathrm{~m}$ soil profile respectively, whereas after common vetch and in plots without green manure only $52 \%$ were found in the topsoil. The much stronger ability of the grasses to concentrate $\mathrm{N}$ in the upper soil layers meant that the shallow-rooted vegetables took up as much $\mathrm{N}$ after the non-legume green manures as after the non-hardy legumes. Thus, growing non-hardy legumes, before shallow-rooted vegetable crops was a very inefficient method of $\mathrm{N}$ supply, as they added much $\mathrm{N}$ to the soil but very little was utilized by the subsequent main crop.

Non-hardy legumes showed much better effects when grown before deep-rooted vegetables, which could utilize much of the $\mathrm{N}$ leached into deeper soil layers during winter. When deep-rooted vegetables were grown after rye or ryegrass, a tendency for reduced yield compared to control plots were observed, due to the reduced amount of $\mathrm{N}$ in the soil profile. The results from this experiment show the importance of root growth information for designing $\mathrm{N}$ efficient crop rotations. 


\section{Literature Cited}

Barraclough, P.B. 1989. Root growth, macro-nutrient uptake dynamics and soil fertility requirements of a high-yielding winter oilseed rape crop. Plant and Soil 119:59-70.

Burns, I.G. 1980. Influence of the spatial distribution of nitrate on the uptake of $\mathrm{N}$ by plants: A review and a model for rooting depth. J.Soil Sci. 31:155-173.

Everaarts, A.P., Demoel, C.P. and Van Noordwijk, M. 1996. The effect of nitrogen and the method of application on nitrogen uptake of cauliflower and on nitrogen in crop residues and soil at harvest. Netherlands Journal of Agricultural Science 44:43-55.

Greenwood, D.J., Gerwitz, A., Stone, D.A. and Barnes, A. 1982. Root development of vegetable crops. Plant and Soil 68:75-96

Greenwood, D.J., Rahn, C., Draycott, A., Vaidyanathan, L.V. and Paterson, C. 1996. Modelling and measurement of the effects of fertilizer- $\mathrm{N}$ and crop residue incorporation on $\mathrm{N}$-dynamics in vegetable cropping. Soil Use And Management 12:13-24.

Jackson, L.E. 1995. Root architecture in cultivated and wild lettuce (Lactuca spp). Plant Cell and Environment 18:885-894.

Jackson, L.E. and Stivers, L.J. 1993. Root distribution of lettuce under commercial production: Implications for crop uptake of nitrogen. Biological Agriculture \& Horticulture 9:273-293.

Kuhlmann, H. 1990. Importance of the subsoil for the K nutrition of crops. Plant and Soil 127:129-136.

Peterson, G.A., Anderson, F.N., Varvel, G.E. and Olson, RA. 1979. Uptake of 15Nlabeled nitrate by sugar beets from depths greater than $180 \mathrm{~cm}$. Agronomy 71:371372.

Rahn, C.R. 1992. Nitrogen residues from brassica crops. Aspects of Applied Biology 30:263-270.

Schenk, M., Heins, B. and Steingrobe, B. 1991. The significance of root development of spinach and kohlrabi for N fertilization. Plant and Soil 135:197-203.

Smit, A.L., Booij, R. and Van der Werf, A. 1996. The spatial and temporal rooting pattern of Brussels sprouts and leeks. Netherlands Journal of Agricultural Science 44:57-72.

Thorup-Kristensen, K. 1993. Root development of nitrogen catch crops and of a succeeding crop of broccoli. Acta Agric.Scand., Sect B, Soil and Plant Sci 43:58-64.

Thorup-Kristensen, K. 1998. Root Growth of Green Pea (Pisum sativum L.) Genotypes. Crop Sci. 38:1445-1451.

Thorup-Kristensen, K. and Bertelsen, M. 1996. Green manure crops in organic vegetable production. In: eds. Kristensen, N.H. and Høeg-Jensen, H. New Research in Organic Agriculture, Proceedings from the $11^{\text {th }}$ International Scientific IFOAM Conference, Copenhagen, pp 75-79.

Thorup-Kristensen, K. and Grevsen, K. 1999. An organic vegetable crop rotation selfsufficient in nitrogen. Nordisk Jordbrugsforskning 81(3):206-214.

Thorup-Kristensen, K. and Nielsen, N.E. 1998. Modelling and measuring the effect of nitrogen catch crops on the nitrogen supply for succeeding crops. Plant and Soil 203:79-89.

Thorup-Kristensen, K. and Sørensen, J.N. 1999. Soil Nitrogen Depletion by Vegetable Crops with Variable Root Growth. Acta Agric.Scand., Sect.B, Soil and Plant Sci 49:92-97.

Thorup-Kristensen, K. and Van den Boogaard, R. 1998. Temporal and spatial root development of cauliflower (Brassica oleracea L. var. botrytis L.). Plant and Soil 201:37-47.

Thorup-Kristensen, K. and Van den Boogaard, R. 1999. Vertical and horizontal development of the root system of carrots following green manure. Plant and Soil 212:145-153

Wehrmann, J., Scharpf, H.-C. and Kuhlmann, H. 1988. The Nmin method - an aid to improve nitrogen efficiency in plant production. In: Jenkinson, D. S. \& Smith, K. A. (ed.) Nitrogen efficiency in agricultural soils. Elsevier, London, pp. 38-45. 
Whitmore, AP. 1996. Modelling the release and loss of nitrogen after vegetable crops.

Netherlands Journal of Agricultural Science 44:73-86

\section{$\underline{\text { Tables }}$}

Table 1. Dates for the various operations in the experiment

\begin{tabular}{|c|c|c|}
\hline Operation & $1996 / 1997$ & 1997/1998 \\
\hline Sowing of green manure & 5 Aug. 1996 & 1 Aug. 1997 \\
\hline Soil and plant sampling, green manure & 14 Nov. & 11 Nov. \\
\hline Incorporation of green manure & 4 Apr. 1997 & 25 Mar. 1998 \\
\hline Sowing of onions & 21 Apr. & 22 Apr. \\
\hline Planting cabbage and lettuce & 02 May & 22 Apr. \\
\hline Sowing carrots & 29 May & 18 May \\
\hline Soil sampling & 15 May & 27 May \\
\hline Harvest lettuce and soil sampling & 24 Jun. & 08 Jun. \\
\hline Harvest cabbage and soil sampling & $16 \mathrm{Jul}$. & $27 \mathrm{Jul}$. \\
\hline Harvest onion and soil sampling & 28 Aug. & 14 Sep. \\
\hline Harvest carrot and soil sampling & 02 Sep. & 21 Sep. \\
\hline
\end{tabular}




\section{Figures}

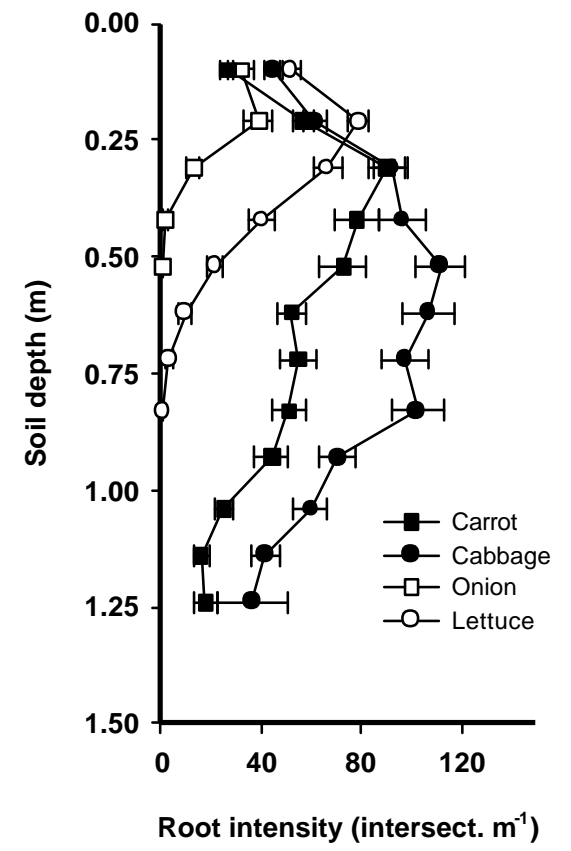

Figure 1. Root distribution (root intensity, i.e. root intersections $\mathrm{m}^{-1}$ of counting line on the minirhizotron surface) under four vegetable crops at harvest. Average of two years and observations beneath and between rows. Error bars show SE.

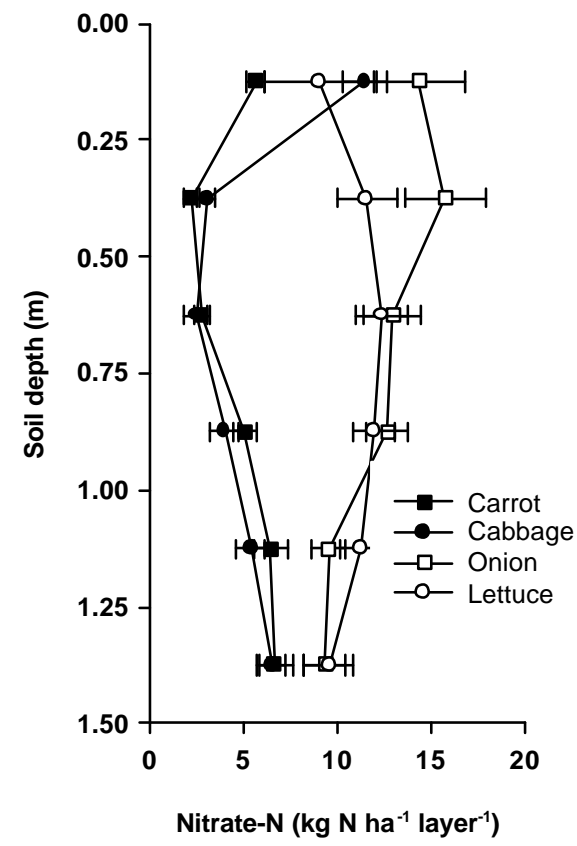

Figure 2. Depth distribution of nitrate-N left in the soil at harvest of the four vegetable crops. Average of two years and three green manure treatments (hairy vetch, common vetch and control). Error bars show SE. 